\title{
Quality of Life in Children with Nephrotic Syndrome at Dr. Moewardi Hospital
}

\author{
Andrew Andy Putra Kartawijaya, Hari Wahyu Nugroho, Fadhilah Tia Nur
}

Department of Child Health, Faculty of Medicine, Universitas Sebelas Maret/

Dr. Moewardi Hospital, Surakarta.

\section{ABSTRACT}

Background: Children with chronic disease often have poor quality of life. Nephrotic syndrome was one of the most common kidney diseases in children with a high number of relapses. Therefore, treatment for nephrotic syndrome might take a long time. Complications from the disease and medications might affect the quality of life of the patient.

Subjects and methods: This was a cross sectional, descriptive analytic study. Children aged 5-18 years old who visited the nephrologic outpatient department of Dr Moewardi general hospital from july to September 2020 and fullfilled the inclusion criteria were included in the study. Quality of life was assessed using PedsQL ${ }^{\mathrm{TM}}$ 4.0 generic module.The analysis of this research was done by using chi-square and logistic regression.

Results: A total of 27 children aged from 5-18 years old participated in this study. Decrease quality of life was reported in $22 \%$ based on report from parents. From parent's report, gender $(\mathrm{OR}=0.06$; $\mathrm{CI} 95 \%=0.01$ to $0.66 ; \mathrm{p}=$ o.008) was associated with decrease of quality of life in children with nephrotic syndrome. Most of the children had decreased quality of life in the psychososial domain according to parent's report $(\mathrm{OR}=4.70 ; 95 \% \mathrm{CI}=1.12$ to 19.70; $\mathrm{p}=0.026$ ).

Conclusion: $22 \%$ children with nephritic syndrome have decreased quality of life. Gender was the risk factors that might contribute to the decreased quality of life of children with nephrotic syndrome.

Keywords: quality of life, children, nephrotic syndrome

\section{Correspondence:}

Andrew Andy Putra Kartawijaya. Department of Pediatrics, Faculty of Medicine, Universitas Sebelas Maret/ Dr. Moewardi Hospital, Surakarta. Jl. Kolonel Sutarto 132, Surakarta, Indonesia. Mobile: 081314749487. email: ciploe_17@yahoo.co.uk.

Cite this as:

Kartawijaya AAP, Nugroho HW, Nur FT (2021). Quality of Life in Children with Nephrotic Syndrome at Dr. Moewardi Hospital. J Matern Child Health. 06(03): 344-352. https://doi.org/10.26911/thejmch.2021.06.03.09.

Journal of Maternal and Child Health is licensed under a Creative Commons Attribution-NonCommercial-ShareAlike 4.0 International License.

BACKGROUND

Nephrotic syndrome was one of the kidney diseases that was commonly found in children and difficult to treat (Trihono et al., 2008). In Indonesia nephrotic syndrome was found in 12-16 per 100,000 children every year (Gibson et al., 2009). In Dr. Moewardi hospital, 70\% children who came to the nephrology outpatient clinic was due to nephrotic syndrome. Nephrotic syndrome was also known for its high relapse rate. Children who had nephrotic syndrome had $60-80 \%$ chance of relapsing (Trihono et al., 2008; Guha et al., 2009). From all those children, 34.8\% patients had a non frequent relapseand $26.4 \%$ patients had frequent relapse. Therefore, we could conclude that most children with nephrotic syndrome would be hospitalized more often 
to get further treatment for their disease (Ali et al., 2008).

Children with nephrotic syndrome needed special diet arrangement, lifestyle modification and closeobservation from medical team (McKenna et al., 2006). This was because of the various compications not only from the disease itself, but also from other the medications given to the children. The side effect of the medications might affect many aspects of their life, such asthe physical, neurological disorders, and psychosocial problems that could affect their quality of life. Children with frequent relapse and steroid resistant would need to consume steroid for a long period of time. This maycause them having a condition which was related to behavior disorder such as depresion, increased aggression, and generalized anxiety disorder (Soliday et al., 2009; Ruth et al., 2004). This disease will not only affect the children but also the family and the caregivers would have a psychosocial burden from this disease (Matza et al., 2004).

Quality of life was someone's subjective perception about his/herwell being. These included physical, psychological, and social domain (Gerson et al., 2010). Most children with a certain chronic disease would have a low quality of life. They usually had a low score on the social, emotional, physical and school domain when compared to the healthy children (Mehta et al., 1995). Several studies also showed that there wasbehavioral disorder such as depression, hyperactivity disorder, and impaired school performance (Soliday et al., 2001; Matza et al, 2004). Aside from that, parenting style also affectedthe quality of life on children with nephrotic syndrome. Parenting style was an important factor that might affect the quality oflife in children with nephrotic syndrome as it includedfamily, environment and childcare environment (Simatupang et al., 2007)

Quality of life was very important to the patients with nephrotic syndrome because they tend to be hospitalized more frequently. These mightcause changes such asgrowth and development impairment (motoric skill and changesindevelopmental of sexual identity and gender-appropriate roles), cognitive disorder (forgetfulness, inability to concentrate, and anxiety), children would often be absent from school, had emotional disorder and social activity disorder. There were several ways to measure the children's quality of life. One of them was by using Pediatric Quality of Life Inventory (PedsQL). PedsQL was a validated questionaires and was adapted internationally and had been converted to English, Germany, Spain, and Indonesian language (Wardin, 2021). These questionnaires could be used by children from 2 - 18 years old. Therefore, the author planned to analyze the quality of life of children with nephrotic syndrome patient's using the PedsQL in Dr. Moewardi Hospital, Surakarta.

\section{SUBJECTS AND METHOD}

\section{Study design}

This was a descriptive analytic study with a cross sectional design conducted in the pediatric nephrology outpatient clinic Dr. Moewardi Hospital Surakarta, from JulySeptember 2020.

\section{Population and sample}

The Study population were children aged 518 years old who was diagnosed with nephrotic syndrome and were treated at least for 6 months. The exclusion criteria were patients who have conditions that prevent them from answerring the questionare, such as children with mental retardation, cerebral palsy and down syndrome. 
Kartawijaya et al./ Quality of Life in Children with Nephrotic Syndrome

A sample of 27 patients was selected by consecutive sampling.

\section{Study variable}

The independent variable wereduration of illness, type of nephrotic syndrome and demographical data (age, sex, parents education, children education, parents occupation, income level, number of children).The Dependent variable was the quality of life which was measured using PedsQL ${ }^{\mathrm{TM}}$

\section{Operational Definition of Variables}

Nephrotic syndrome, the diagnosis was obtained from the medical record

Quality of life, PedsQL ${ }^{\mathrm{TM}}$ questionaire were used to measure the quality of life. The questionaire were grouped by the age of patients. Questionaire consists of parents report from the children age 5-7 yo, 8-13 yo, and 13-18 yo. There were 4 domains in this questionaire, physical, social, emotion, school. Every domain consists of 5 response scales $(\mathrm{O}=$ never, $1=$ rarely, $2=$ sometimes, $3=$ often, 4= always). Score from every domain will be converted to 0-100, with conversion rate $(0=100,1=75,2=50,3=$ 25, 4=0). Children who have a total score above 70 means that their quality of life were good. While they who have a total score below 70 means their quality of life were poor.

Age was obtained from the medical records. They were grouped according to the PedsQL ${ }^{\mathrm{TM}}$ questionaire, i.e.5-7 yo, 8-12 yo, 13-18 yo.

Gender was differentiated to male and female.

Order of Children were differentiatedto the first children or not.

Total of children were differentiated to two children or more than two.

Duration of illness was how long the patient had this disease from the first-time patient was diagnosed.
Education status was obtained by interviewing the parents. Education was differentiated to uneducated, primary school, junior high school, senior high school in accordance to the Republic of Indonesia Law No. 20 of 2003.34.

Occupation was differentiated by parents by working or not.

Family income levelwas obtained from the interview with the parents and was differentiated to under regional minimum wage ( $R p<1,500,000 /$ month) and above regional minimum wage $(\mathrm{Rp}>1,500,000 /$ month) in accordance with the regional minimum wage in Central Java Provence (Central Java Government, 2020).

\section{Study instrument}

Demographical data was acquired interviewing the parents of the patients. The medical condition of the patients was acquired from the medical record and the patients' quality of life was acquired from thePEDSQL ${ }^{\text {tm }}$ questionaire

\section{Data Analysis}

Data were analyzed using Software Package for Social Science (SPSS) version 21 software. Bivariate analysis was analyzed using chi-square with $\mathrm{p}$ value $<0,05$ that would be included in multivariate analysis. Logistic regression was uesd for the multivariate analysis.

\section{Research ethics}

This study was approved by the Health Research Ethics Committee of Dr. Moewardi Hospital, Surakarta, No 703/VI/HREC/202O.

\section{RESULTS}

1. Sample characteristics

There was a total of 27 children included in this study. The majority of children with nephrotic syndrome were male (63\%) and aged $13-18$ years old (48\%), followed by age 8-12 years old (33\%). Most of the patients were still in the elementary school (44\%) 
Kartawijaya et al./ Quality of Life in Children with Nephrotic Syndrome

and having the parents with educational status mostly senior high school (52\%). The majority of children have intact families (67\%) and their parents had jobs (78\%) with income mostly below the minimum wage $(85 \%)$.Duration of ilnessof patients

Table 1. Characteristics of subjects

\begin{tabular}{llll}
\hline Characteristics & Category & Frequency & Percentage \\
\hline Gender & Male & 17 & $63 \%$ \\
Age & Female & 10 & $37 \%$ \\
& $5-7$ years old & 5 & $19 \%$ \\
\multirow{5}{*}{ Education of children } & $8-12$ years old & 9 & $33 \%$ \\
& $13-18$ years old & 13 & $48 \%$ \\
& Primary school & 12 & $44 \%$ \\
Order of children & Junior high & 7 & $26 \%$ \\
& Senior high & 8 & $30 \%$ \\
Single parrent & First born & 4 & $15 \%$ \\
& Not first born & 23 & $85 \%$ \\
Education of parents & Yes & 10 & $37 \%$ \\
& No & 17 & $63 \%$ \\
& Uneducated & 1 & $4 \%$ \\
& Primary school & 5 & $19 \%$ \\
Occupation & Junior high & 7 & $26 \%$ \\
\multirow{2}{*}{ Total family income } & Senior high & 14 & $51 \%$ \\
& Working & 21 & $78 \%$ \\
& Not working & 6 & $22 \%$ \\
\hline
\end{tabular}

\section{Bivariate Analysis}

Based on the parent's report, gender $(\mathrm{OR}=$ 0.06, 95\% CI= 0.01-0.66, $\mathrm{p}=0.008)$ was

Table 2.The association between demographic factors and QoL of NS children based on parent's report

\begin{tabular}{|c|c|c|c|c|c|c|}
\hline \multirow[b]{2}{*}{ Variables } & \multicolumn{2}{|c|}{ Quality of Life $(n=27)$} & \multirow[b]{2}{*}{ OR } & \multicolumn{2}{|c|}{$95 \%$ CI } & \multirow[b]{2}{*}{$\mathbf{p}$} \\
\hline & Disturbed & $\begin{array}{c}\text { Not } \\
\text { disturbed }\end{array}$ & & $\begin{array}{l}\text { Lower } \\
\text { limit }\end{array}$ & $\begin{array}{l}\text { Upper } \\
\text { limit }\end{array}$ & \\
\hline Gender & & & 0.06 & 0.01 & 0.67 & 0.008 \\
\hline Male & 1 & 16 & & & & \\
\hline Female & 5 & 5 & & & & \\
\hline \multicolumn{7}{|l|}{ Age } \\
\hline 5-7 years old & 2 & 3 & & & & \\
\hline 8-12 years old & 3 & 6 & 0.75 & 0.08 & 7.21 & 0.803 \\
\hline 13-18 years old & 1 & 12 & 0.17 & 0.01 & 1.96 & 0.125 \\
\hline \multicolumn{7}{|l|}{ Education of children } \\
\hline Primary school & 4 & 8 & & & & \\
\hline Junior high & 1 & 6 & 0.33 & 0.03 & 3.80 & 0.363 \\
\hline Senior high & 1 & 7 & 0.86 & 0.04 & 16.85 & 0.919 \\
\hline Order of children & & & 4.75 & 0.51 & 44.48 & 0.148 \\
\hline First born & 2 & 2 & & & & \\
\hline Not first born & 4 & 19 & & & & \\
\hline Single parent & & & 0.81 & 0.12 & 5.49 & 0.831 \\
\hline Yes & 2 & 8 & & & & \\
\hline
\end{tabular}

associated with decrease of quality of life in

children with nephrotic syndrome. who participated in this study varied greatly from a minimum of 7 months and a maximum of 8 years and 8 months. Almost all the patients were still using steroidsat the time of study and only 1 patient was not taking steroids. 
Kartawijaya et al./ Quality of Life in Children with Nephrotic Syndrome

\begin{tabular}{|c|c|c|c|c|c|c|}
\hline \multirow{2}{*}{\multicolumn{7}{|c|}{$\begin{array}{l}\text { No } \\
\text { Education of parents }\end{array}$}} \\
\hline & & & & & & \\
\hline Uneducated & 1 & 0 & & & & \\
\hline Primary school & 2 & 3 & NA & NA & NA & 0.273 \\
\hline Junior high & 2 & 4 & 0.75 & 0.06 & 8.83 & 0.819 \\
\hline Senior high & 1 & 14 & 0.14 & 0.01 & 2.01 & 0.115 \\
\hline Occupation & & & 0.17 & 0.02 & 1.25 & 0.063 \\
\hline Working & 3 & 18 & & & & \\
\hline Not working & 3 & 3 & & & & \\
\hline Total family income & & & NA & NA & NA & 0.247 \\
\hline Above regional minimum wage & 6 & 17 & & & & \\
\hline $\begin{array}{l}\text { Under regional minimum wage } \\
\text { NA: not computable }\end{array}$ & o & 4 & & & & \\
\hline
\end{tabular}

There was also no significant association of nephrotic syndrome with the quality of between the duration of illness and the type life of children with nephrotic syndrome.

Table 3.The association between duration of illness, type of NS and QoL of NS children based on parent's report

\begin{tabular}{|c|c|c|c|c|c|c|}
\hline \multirow[b]{2}{*}{ Variables } & \multicolumn{2}{|c|}{ Quality of Life $(n=27)$} & \multirow[b]{2}{*}{ OR } & \multicolumn{2}{|c|}{$95 \% \mathrm{CI}$} & \multirow[b]{2}{*}{$\mathbf{p}$} \\
\hline & Disturbed & Not disturbed & & $\begin{array}{l}\text { Lower } \\
\text { limit }\end{array}$ & $\begin{array}{l}\text { Upper } \\
\text { Limit }\end{array}$ & \\
\hline Duration of ilness & & & & & & \\
\hline $0.5-1$ years & 2 & 8 & 17.09 & 1.33 & 0.10 & 0.825 \\
\hline 1- 2 years & 1 & 4 & & & & \\
\hline$>2$ years & 3 & 9 & & & & \\
\hline $\begin{array}{l}\text { Type of nephrotic } \\
\text { syndrome }\end{array}$ & & & 10.08 & 1.50 & 0.22 & 0.675 \\
\hline Frequent relapse & 2 & 9 & & & & \\
\hline Steroid resistant & 4 & 12 & & & & \\
\hline
\end{tabular}

Based on the parent's report, we found that children with nephrotic syndrome had lower scoring on the psychosocial domain compared to the physical domain. $(\mathrm{OR}=4 \cdot 70$, CI95\%= 1.12-19.70, $\mathrm{p}=0,026)$.

Table 4. The association between the domain of QoL and overall QoL of NS children based on parents's report

\begin{tabular}{lcccccc}
\hline \multirow{2}{*}{ Group } & \multicolumn{2}{c}{ Quality of Life (n=27) } & \multirow{2}{*}{ OR } & \multicolumn{2}{c}{$\mathbf{9 5 \%}$ CI } & p \\
\cline { 2 - 3 } \cline { 5 - 6 } & Disturbed & Not disturbed & & Lower limit & Upper Limit & \\
\hline Physical & 3 & 24 & 4.71 & 1.12 & 19.70 & 0.026 \\
Psychosocial & 10 & 17 & & & & \\
\hline
\end{tabular}

\section{DISCUSSION}

1. The association between demographic factors and QoL of children with NS

In our study there were $22 \%$ children with nephrotic syndrome based on the parent's report that score below 70 on the PedsQL ${ }^{\mathrm{TM}}$ questionaire. This was different from reports originating from the children, which only showed $19 \%$ who experienced a decrease in quality of life. This result was similar to the study done by Pardedeet al.(2015) that stated that $19 \%$ of children with nephrotic syndrome had decreased quality of life according to parent and child reports. The difference in the results could 
be caused by the differences in methodology, number of subjects and the inclusion and exclusion criteria that were used in our study.The number of subjects obtained in this study was relatively smaller compared to oher study because this study was done during the Covid-19 pandemic, therefore many patients might postponed coming to the hospital due to the difficulty of transportation and economy during this pandemic era. As we could see in the results of our study that the majority of our patients had income below regional minimum wage hence this could also be one of the reasons why our patients did not come for treatment.

Majority of our patients were male (63\%). This result was similar to a study done by Al Qaisy et al. (2019). In their study the male to female ratio was 2:1. However, until now it cannot be explained with certainty why male have a greater incidence than women. Our study also found out that according to the parent's report female children with nephrotic syndrome had lower quality of life score compared to the male children.This could be due to cultural, ethnic, socio-economic and daily habits in Asian people.

Based on age groups, the majority of our patients were in the 13-18 years group (48\%). This result was different from the study done by Agrawal et al.(2017) and Pardede et al.(2015) who showed that the dominant age of patients with nephrotic syndrome was 8-12 years old. During these age group children enters puberty, where during this phase there would be many changes that occured in their body. These changes included intellectual, emotional, developmental and social so that this could changed their assessment about their quality of life. This was shown in our study, as age was not statistically significant in affecting the quality of life in children with nephrotic syndrome.

According to Rosita et al.(2012) the number of children, order of children and number of caregivers have a role in regards of the quality of life of the child. The fewer number of children and complete parents indicated that parents had more time to consult with the medical personel and gotten more comprehensive information about children's diseases compared to those parents who had many children or children who only have one parent but this was not shown in our study.

Parent's education, occupation and income were a triad that influence each other in determining the quality of life of a child.The higher the education of the parents, the more obedient they would be in seeking treatment and obeying the advice given by the medical personel (Nilawati., 2016). In our study we found that the majority of parents were high school graduates (51\%) but from our analysis, it showed that parental education, occupation and family income did not have a statistically significant result on the child's quality of life.This result differed from the study done by Pardede et al. (2015) who found that parent's education affected the quality of life of children. The difference in results between our study and theirs could be due to the small number of samples in our study. This could be seen in the wide confidence interval value (0.068.83).

Our institution was a government hospital hence majority of the patients who came were people with economic status from the middle to lower class. This was reflected in their monthly income, the majority of which are below the UMR.This result was also found by Pardede et al. (2015) and Rosita et al.(2012). 


\section{The association between duration of illness, type of NS and QoL children with NS}

According to the study done by Youssef et al. (2013) that prolonged steroid usage could lead to abnormal behavior in children with nephrotic syndrome. Downie et al. (2017) also stated that one of the side effects of consuming steroid was obesity. This side effect occured in children who received steroids for more than 6 months and would last for several months more even though they had stopped taking steroids. Obesity would cause the child to become insecure or subject of bullying by their peers so that it could affect the mental aspects of children with nephrotic syndrome. A study by Rosita et al. (2012) also stated that the longer therapy the patient must undergo, the worse the patient's quality of life would be. However, this was not seen in our study. The difference in results between our study and theirs could be due to the small number of samples in our study. This could be seen in the wide confidence interval value (o.o614.64)

Our study showed that children with steroid-resistant NS were more likely to experience a decrease in quality of life than those with frequent relapses. However, based on the bivariate analysis, the results were not statistically significant. The same result was obtained by Pardede et al. (2015) and Nilawati (2016). This could be caused by the so-called "response shift" phenomenon. This phenomenon was the result of changes in individual internal standards, personal values, perceptual concepts, thus affecting behavior, cognitive and affective mechanisms of how a person able to managed their problems that were caused by the disease.

\section{The association between the domain of QoL and overall QoL of NS children}

In a study by Rousel et al. (2019) of the 4 domains tested, children with nephrotic syndrome did have lower scores than other normal children, especially in the school domain.This happened because the child often came to the hospital for treatment so that the child was often absent from school.Different results were also found by $\mathrm{Al}$ Qaisy et al. (2019) and Agrawal et al. (2017), according to the results of their study, there were no statistically significant differences between the 4 domains. The result of our study was similar to that of theirs. This could be seen from theresults of theparent'sreports, there was a significant decreased in the quality of life of children in the psychosocial domain. This could be caused by the side effects from prolonged use of steroid. The side effects of steroids could change the physical appearance of the child; hence he/she might be often teased at school and ostracized. All this could affect children self esteemed hence he/she might get depressed, stressed and not confident in themselves(Ngozi et al., 2018).

From this study it could be concluded that as many as $22 \%$ of children with nephrotic syndrome had decreased quality of life. Gender and parent's occupation were risk factors that cause a decreased in the quality of life of children with nephrotic syndrome. Out of the 4 domains being tested, children with nephrotic syndrome had lower scoring in the psychosocial domain than the physical domain. The advantages of this research were since this was a cross sectional study, many variables could be analyzed and the time needed to conduct this study was not long because the PEDSQL questionnaire was easy to use. Another limitation of this study was that the research design used was cross- 
sectional, so that it was not possible to determine the exposure or the cause of the disease in advance. This was because data collection was done at the same time.

\section{AUTHOR CONTRIBUTION}

Andrew Andy Putra was the main author who conducted the study, processed data analysis, and wrote the manuscript. Hari Wahyu Nugrohoexamined the background and discussion of the study dan Fadhilah Tia Nur formulated the framework of study.

\section{CONFLICT OF INTEREST}

There was no conflict of interest in this study.

\section{FUNDING AND SPONSORSHIP}

This study was self-funded.

\section{ACKNOWLEDGMENT}

The author gratefully acknowledged Dr. Moewardi General Hospital and study participants who had volunteered to participate in this study.

\section{REFERENCES}

Agrawal S, Krishnamurthy S, Naik B (2017). Assessmment of quality of life in children with nephritic syndrome at a teaching hospital in South India. Saudi J Kidney Dis Transpl. 28(3): 593-598. https://doi.org/10.4103/1319-2442.206452.

Ali A, Ali D, Mehran H, Ali Z (2008). Idiopathic nephrotic syndrome in Iranian children. Indian Pediatrics. 45(1): 5253. https://pubmed.ncbi.nlm.nih.gov/18250507/.

Al Qaisy UK, Ali SH, Ali IH (2019). Assessment of health-related Quality of life in children with nephroticc syndrome in Iraq- A comparative study. Indian J Public Health Res Develop. (10): 2657-2662.
Downie M, Gallibois, Parekh R, Noone D (2017). Nephrotic syndrome in infants and children: pathophysiology and management. Paediatrics Int Child Health. 37(4): 248-258. https://doi.org/10.1080/20469047.2017.137400 3.

Gerson AC, Wentz A, Abraham AG, Mendley SR, Hooper SR, Butler RW (2010). Health- related quality of life of children with mild to moderate chronic kidney disease. Pediatrics. 125(2): e349-357. https://dx.doi.org/10.1542\%2Fpeds.2009-0085.

Gipson DS, Massengill SF, Yao L, Nagaraj S, Smoyer W, Mahan JD, et al. (2009). Management of childhood onset nephrotic syndrome. Pediatrics. 124(2): 747-757. https://doi.org/10.1542/peds.2008-1559.

Gubernur Jawa Tengah (2020). Upah minimum pada 35 (tigapuluh lima) kabupaten/kota Di provinsi jawa tengah tahun 2020. Gubernur jawa tengah; Semarang.

Guha P, De A, Ghosal M (2009). Behavior profile of children with nephrotic syndrome. Indian J Psychiatry. 51(2): 122-126. https://dx.doi.org/10.4103\%2Fo019-5545.49452.

Matza LS, Swensen AR, Flood EM, Secnik K, Leidy NK (2004). Assessment of health- related quality of life in children: a review of conceptual, methodological, and regulatory issues. Value Health; 7(1): 79-92. https://doi.org/10.1111/j.1524-4733.2004.71273.x.

McKenna AN, Keating LE, Vigneux A, Stevens S, Williams A, Geary DF (2006). Quality of life in children with chronic kidney disease-patient and caregiver assessments. Nephrology Dialysis Transplantation. 21(7): 18991905. https://doi.org/10.1093/ndt/gflo91. 
Kartawijaya et al./ Quality of Life in Children with Nephrotic Syndrome

Mehta M, Bagga A, Pande P, Bajaj P, Srivastava $R N$ (1995). Behavior problem in nephrotic syndrome. Indian Pediatr. 32(12): 1281-1286. https://pubmed.ncbi.nlm.nih.gov/8772885/.

Nilawati G (2016). Profil Sindrom Nefrotik pada Ruang Perawatan Anak RSUP Sanglah Denpasar. Sari Pediatri; 14(4): 269. https://dx.doi.org/10.14238/sp14.4.2012.269-72.

Pardede S, Marsubrin PMT, Sekartini R, Munasir Z (2019). Quality of life of nephrotics children and its related factors. Am J Clin Med Res. 7(1): 3136. https://doi.org/10.12691/ajcmr-71-6.

Rosita IR, Muryawan MH (2012). Perbedaan kualitas hidup anak dengan sindrom nefrotik resisten steroid dan sindrom nefrootik relaps. Medica Hospitalia. 1(1): 42-46. https://doi.org/10.36408/mhjcm.v1i1.39.

Roussel A, Delbet JD, Micheland L, Deschênes G, Decramer S, Ulinsk (2019). Quality of life in children with severe forms of idiopathic nephritic syndrome in stable remission- A crosssectional study. Acta Paediatrica. 108(12): 2267-2273. https://dx.doi.org/10.1111/apa.14912ff.ffhal-o2361199.

Ruth EM, Landolt MA, Neuhaus J, Kemper MJ (2004). Health-related quality of life and psychosocial adjustment in steroid-sensitive nephrotic syndrome. J Pediatrics. 145(6): 778-783. https:- //doi.org/10.1016/j.jpeds.2004.08.02 2.

Simatupang DF, Damanik MP, Sadjimin T (2007). Perbedaan tingkat kualitas hidup anak dengan sindrom nefrotik primer kelainan minimal dan bukan kelainan minimal di RSUP Dr. Sardjio Yogyakarta. Sari Pediatri. 9(3): 220226. https://dx.doi.org/10.14238/sp9.3.2007.220-6.

Soliday E, Kool E, Lande MB (2001). Family environment, child behavior, and medical indicators in children with kidney disease. Child Psychiatry Hum Dev. 31(4): 279-95. https://doi.org/10.1023/a:1010282305881.

Trihono PP, Alatas H, Tambunan T, Pardede SO (2008). Konsensus tata laksana sindrom nefrotik idiopatik pada anak. Edisi kedua. UKK Nefrologi IDAI.

Wardin I (2021). Uji validitas dan reliabilitas the pediatric quality of life inventory multidimentional fatigue scale versi Indonesia (PedsqlMfs-I) pada anak yang menjalani kemoterapi. Jurnal Ilmu Kesehatan, 9(2). Retrieved from https://e-journal.umc.ac.id/index.php/JIK/article/view/168 3 .

Youssef D, Abdelsalam M, Abozeid A, Youssef U (2013). Assessment of behavior abnormalities of corticosteroids in children with nephrotic syndrome. ISRN Psychiatry. 013: 921253. https://doi.org/10.1155/2013/921253. 